\title{
Kidney Cancer pT3b TNM Finding v8
}

National Cancer Institute

\section{Source}

National Cancer Institute. Kidney Cancer pT 3b TNM Finding v8. NCI Thesaurus. Code C140293.

Kidney cancer in which the tumor extends into the vena cava below the diaphragm. (from AJCC 8th Ed.) 